Diana Maksimiuk

\title{
Dyskusja nad projektem kodeksu karnego z 1956 r. w czasopismach prawniczych
}

Keywords: Draft of penal code 1956

\section{Summary}

After World War II the communists, who took power in Poland, did not abolish the old penal code from 1932. However, the new acts on penal law were passed and they were undermining the old system and in fact creating the new one. This situation was criticized by new authorities and in 1950 works on new penal code were inaugurated. It was expected that new code will be ready in one year. However, the reality was completely different and the penal code of so called People's Poland came into force not earlier than in 1970. The works on new penal code have been going on for a very long time. The Ministry of Justice prepared first draft in 1956. It was published and consulted among specialists. The penal lawyers criticized the draft strongly and it was rejected. The rejection was connected with the new era in communist Poland after Stalin's death.

Problematyka kodyfikacji prawa karnego w Polsce Ludowej stała się już przedmiotem zainteresowania badaczy ${ }^{1}$. Zwrócono uwagę, iż w pierwszych latach funkcjonowania nowej władzy, nie uchylając przepisów dwóch przedwojennych kodeksów: karnego z 1932 r. i postępowania karnego z 1928 r., równolegle ukształtowano odrębny system prawny, wprowadzając nowe normy prawa materialnego i procesowego. Takie rozwiązanie umożliwiało władzom prowa-

${ }_{1}$ M.in. A. Lityński, Pół wieku kodyfikacji prawa w Polsce (1919-1969). Wybrane zagadnienia, Tychy 2001, s. 79-86; Idem, O prawie i sądach początków Polski Ludowej, Białystok 1999, s. 126-127; A. Grześkowiak, Aksjologia komunistycznego prawa karnego, [w:] Komunistyczne prawo karne Polski Ludowej, red. A. Grześkowiak, Lublin 2007, s. 22. 
dzenie walki o utrwalenie „władzy ludowej”, czyli niszczenie opozycji politycznej, a także kształtowanie nowej rzeczywistości gospodarczej². Poza tym, na co zwrócił uwagę A. Lityński, sprawa zmian kodeksów nie budziła zainteresowania wśród praktyków, bo były one „bardzo dobre i nie należało się spodziewać ich naprawienia, ale czegoś przeciwnego"3. Stąd problem kodyfikacji prawa karnego, przynajmniej do 1947 r., po prostu nie istniał. Sygnalizowane przez Ministerstwo Sprawiedliwości propozycje zmian szły w kierunku inkorporacji nowych przepisów do kodeksu karnego z 1932 r., a powołana Komisja Kodyfikacji Prawa Karnego przy Ministerstwie Sprawiedliwości otrzymała zadanie tylko „dostosowania" przepisów prawa karnego do zasad ustrojowych Polski ${ }^{4}$.

„[...] konieczność zbudowania nowego systemu prawa karnego, nowego kodeksu karnego, opartego na zasadach naukowych marksizmu-leninizmu, na doświadczeniu prawa karnego ZSRR" ${ }^{5}$ zaczęto dostrzegać po zdemaskowaniu $i$ zlikwidowaniu odchylenia prawicowo-nacjonalistycznego w 1948 r. Pierwszy krok stanowiła adaptacja doktryny radzieckiego prawa karnego i dokonanie w 1949 r. istotnych zmian w procedurze, pogłębionych w roku $1950^{6}$.

Prace przygotowawcze nad projektem kodeksu karnego zapoczątkowała uchwała Prezydium Rządu z 27 września 1950 r. ${ }^{7}$ Zlecono w niej Ministerstwu Sprawiedliwości trudne zadanie - przygotowanie między innymi kodeksu karnego do 1 września 1951 r. Prace podjęte przez Komisję Konsultacyjno-Naukową przy Ministerstwie Sprawiedliwości z udziałem przedstawicieli nauki i wymiaru sprawiedliwości zaowocowały przygotowaniem początkowo części ogólnej, a następnie całości pierwszego projektu kodeksu karnego. Projekt ten (opublikowano drukiem część ogólną projektu) został przekazany do oceny merytorycznej komisji międzyresortowej, która dokonała poprawek i przekazała go pod dyskusję zarówno teoretyków, jak i praktyków prawa. Uczyniono to w nadziei, iż głosy ich „przyczynią się w znacznym stopniu do tego, by kodeks karny Polski Ludowej jak najlepiej służył ochronie naszego Państwa i rozwoju budownictwa socjalistycznego oraz utrwaleniu praworządności ludowej”. Projekt ten nie został jednak pozytywnie oceniony9. Podnoszono wówczas niezadowalające rozwiązanie problemu winy, nadmierną deklaratywność, niejasne sformułowanie

2 W latach 1944-1954 wydano ponad sto dekretów i ustaw karnych lub zawierających przepisy karne. M. Kallas, A. Lityński, Historia ustroju i prawa Polski Ludowej, Warszawa 2003, s. 293.

A. Lityński, Pół wieku kodyfikacji prawa..., s. 79.

${ }^{4}$ Zebranie organizacyjne Komisji Kodyfikacji Prawa Karnego, „Demokratyczny Przegląd Prawniczy" (dalej: DPP) 1947, nr 10, s. 41..

${ }^{5}$ L. Lernell, Z problematyki prawa karnego w okresie Planu Sześcioletniego, DPP 1950, nr 5, s. 24.

${ }^{6}$ A. Lityński, O prawie i sądach..., s. 126.

7 Monitor Polski Nr A106, poz. 1339.

${ }^{8}$ Projekt kodeksu karnego Polski Ludowej. Część ogólna, Warszawa 1951, s. 40.

9 Zob. sprawozdanie z dyskusji nad projektem części ogólnej kodeksu karnego Polski Ludowej, „Państwo i Prawo” (dalej: PiP) 1952, nr 1, s. 87-98. 
stanu społecznego niebezpieczeństwa, brak definicji błędu, wadliwe rozwiązanie wpływu alkoholu na odpowiedzialność sprawcy itp. Pomimo to stanowił on wciąż podstawę do dalszych prac. W kolejnych latach był poprawiany i w lutym 1955 r. ponownie został poddany dyskusji na naradzie teoretyków i praktyków w Ministerstwie Sprawiedliwości ${ }^{10}$. Zgłoszone wówczas przez dyskutantów również uwagi krytyczne zostały wykorzystane $\mathrm{w}$ dalszych pracach nad projektem kodeksu karnego, których efektem stała się kolejna redakcja projektu z 1956 r. $^{11}$ Tym razem postanowiono nie popełniać błędu jaki dotychczas towarzyszył pracom nad projektem, a za który uważano opracowywanie kodeksu karnego bez udziału szerokiego kręgu opinii publicznej. Na IV Zjeździe Prawników Polskich (17-19 XII 1955) w Warszawie minister sprawiedliwości Henryk Świątkowski zapowiedział ogłoszenie tym razem pełnego tekstu projektu i poddanie go pod dyskusję nie tylko w środowiskach prawniczych, ale i „wśród szerokich rzesz społeczeństwa" 12 .

Zgodnie z zapowiedziami projekt ukazał się drukiem w marcu 1956 r. $^{13}$ i stanowił próbę kodyfikacji prawa karnego Polski Ludowej. Cel, jaki przyświecał pracom, to m.in. uporządkowanie i usystematyzowanie ustawodawstwa karnego, by (jak pisał jeden $\mathrm{z}$ autorów projektu) „ułatwić życie i pracę sędziom, prokuratorom, adwokatom, którzy będą mogli w jednym, niewielkim zresztą, tomie znaleźć wszystko, co im potrzebne w praktyce"14. Taka argumentacja spowodowała, iż w jednym akcie prawnym umieszczono prawo karne powszechne, wojskowe, skarbowe, celne itd. W rzeczywistości projekt stanowił niedostatecznie zharmonizowany „zlepek” przepisów z kodeksu karnego z 1932 r., z kodeksu karnego Wojska Polskiego, z małego kodeksu karnego oraz z kilkunastu ustaw szczególnych, do którego „wtłoczono” także nowe przepisy.

W części ogólnej projektu zamieszczono następujące rozdziały:

1. Założenia ogólne.

2. Zakres stosowania ustawy karnej.

3. Zasady odpowiedzialności karnej.

4. Postacie popełnienia przestępstwa.

5. Kara.

${ }^{10}$ Zob. sprawozdanie z dyskusji nad projektem części ogólnej kodeksu karnego Polski Ludowej, PiP $1955 \mathrm{nr}$ 6, s. 966-984. Wobec nieopublikowania drugiej redakcji projektu k.k. w sprawozdaniu z dyskusji nie uwzględniano na ogół propozycji zmian poszczególnych przepisów czy sformułowań projektu.

${ }^{11}$ Poczynione w projekcie zmiany były już tylko poprawkami stylistycznymi i językowymi. M. Siewierski, Dyskusja nad projektem kodeksu karnego, „Biuletyn Naczelnej Rady Adwokackiej” (dalej: BNRA) 1956, nr 2, s. 40.

${ }^{12}$ O szersza dyskusję w związku z pracami kodyfikacyjnymi, PiP 1956, nr 3, s. 417.

${ }^{13}$ Projekt kodeksu karnego Polskiej Rzeczypospolitej Ludowej i przepisy wprowadzające, Warszawa 1956.

${ }^{14}$ L. Lernell, Niektóre uwagi do projektu kodeksu karnego PRL, „Wojskowy Przegląd Prawniczy” (dalej: WPP) 1956, nr 2, s. 129-130. 
6. Kary samoistne.

7. Kary dodatkowe.

8. Wymiar kary.

9. Warunkowe zawieszenie i odroczenie wykonania kary.

10. Przedterminowe warunkowe zwolnienie.

11. Przedawnienie.

12. Zatarcie skazania.

13. Zasady odpowiedzialności nieletnich.

14. Przepisy wyjaśniające.

W części szczególnej kodeksu zaś zgrupowano w ośmiu rozdziałach następujące rodzaje przestępstw:

1) przestępstwa przeciwko podstawom politycznym i gospodarczym PRL ( $w$ rozdziale tym zamieszczono przestępstwa przeciwko państwu ludowemu, przeciwko pokojowi, ludzkości i pokojowej współpracy międzynarodowej oraz przestępstwa przeciwko własności społecznej);

2) przestępstwa przeciwko obywatelowi i jego prawom (przestępstwa przeciwko życiu i zdrowiu człowieka, przestępstwa przeciwko wolności i godności człowieka, przeciwko małżeństwu i rodzinie, przeciwko młodzieży, przestępstwa przeciwko prawom pracownika, przeciwko wolności sumienia i wyznania, przeciwko prawom wyborczym oraz własności osobistej i indywidualnej obywatela);

3) przestępstwa przeciwko instytucjom państwowym i społecznym oraz ich działalności (w rozdziale tym przewidziano sankcje karne za przestępstwa służbowe, przeciwko tajemnicy państwowej, przestępstwa przeciwko wymiarowi sprawiedliwości oraz przeciwko działalności organów państwowych i instytucji społecznych);

4) przestępstwa przeciwko powszechnemu bezpieczeństwu życia, zdrowia lub mienia (do tej grupy przestępstw zaliczono przestępstwa polegające na wywołaniu klęski żywiołowej lub katastrofy w komunikacji oraz przestępstwa przeciwko zdrowiu powszechnemu);

5) przestępstwa przeciwko porządkowi publicznemu (przepisy zawierające sankcje za publiczne lżenie lub wyszydzanie ustroju, rozpowszechnianie fałszywych wiadomości, niszczenie dzieł sztuki, kultury, uszkadzanie pomników, branie udziału w tajnej organizacji lub grupie zorganizowanej dla dokonywania rabunków, za chuligańskie wybryki, fałszowanie dokumentu, wykonywanie bez zezwolenia zawodu, na wykonywanie którego zezwolenie jest potrzebne, przekroczenie granicy itp.);

6) przestępstwa przeciwko gospodarce narodowej (podzielono je na przestępstwa gospodarcze i przestępstwa finansowe oraz celne);

7) przestępstwa przeciwko obowiązkowi służby wojskowej;

8) przestępstwa wojskowe (przestępstwa przeciwko obowiązkowi wierności żołnierskiej, przeciwko obowiązkowi odbywania służby wojskowej, prze- 
ciwko karności, przeciwko wojskowym obowiązkom służbowym, przeciwko mieniu wojskowemu i inne przestępstwa wojskowe).

Pierwsze głosy o projekcie kodeksu karnego pojawiły się bardzo szybko w czasopismach nie tylko prawniczych, bo już w maju 1956 r. Liczne artykuły ${ }^{15}$ powstawały na fali ożywczego prądu, jaki przyniósł ze sobą XX Zjazd KPZR (14-25 luty 1956), na którym Nikita Chruszczow wygłosił swój słynny referat O kulcie jednostki i jego następstwach. Miał on szczególne znaczenie w procesie ideologicznej destalinizacji, który zapoczątkowała w 1953 r. śmierć Stalina. Proces ten nazwany „odwilżą” cechowała postępująca wolność wypowiedzi. Wtedy to prasie częściowo udało się wyrwać spod nadzoru cenzury. Redaktorzy uzyskali niespotykaną do tej pory swobodę i starali się ją wykorzystać ${ }^{16}$. Z jaką oceną w podjętej dyskusji spotkał się ów projekt? Jak „wypadł” w oczach środowiska prawniczego?

Różne wątki kodeksu znalazły się w kręgu zainteresowania przedstawicieli doktryny. Można by je w ramach niniejszego artykułu ukazać, ale za główny cel mojego opracowania przyjęłam przedstawienie zagadnień, które wzbudziły największe zainteresowanie wśród dyskutantów, szczególnie że w wielu wypadkach stanowiły nowe rozwiązania w dotychczasowym ustawodawstwie karnym, jak choćby problematyka chuligaństwa.

Autorzy zabierający głos na łamach czasopism prawniczych w zdecydowanej większości podjęli problematykę systematyki projektu i przyjętych zasad techniczno-legislacyjnych, choć nie zabrakło ocen opartych na kryteriach politycznych i społeczno-praktycznych. Wyrażano żal, iż twórcy projektu nie opublikowali go wraz z uzasadnieniem, a jedynie opatrzyli krótkim wstępem obrazującym historię pracy nad projektem oraz niezwykle skąpą charakterystyką ogólną. Charakterystyka ta ograniczała się do wyliczenia zalet części ogólnej projektu i czternastu uwag objaśniających układ jego części szczególnej. Jak pisał J. Potępa, brak „uzasadnienia, a także nieopracowanie i nieogłoszenie (poza nielicznymi artykułami dyskutantów) protokołów dyskusji zorganizowanej przez Zrzeszenie Prawników Polskich jest poważnym brakiem i zmarnowaniem dorobku myśli prawniczej” ${ }^{17}$. Brak ten odczuwano głównie tam, gdzie projekt wprowadzał pojęcia znacznie odbiegające od dotychczasowych, łamiąc konstrukcje pochodzące nie tylko od twórców kodeksu karnego z 1932 r., ale także mocno ugruntowane w orzecznictwie sądowym Polski Ludowej ${ }^{18}$.

Podnoszono, że nie jest wskazane łączenie kodeksu karnego powszechnego z kodeksem karnym wojskowym. Jak twierdzono, takie rozwiązanie spowodo-

${ }^{15}$ Leszek Kubicki podawał, iż „[...] szereg pism powracało do zagadnienia projektu kodeksu karnego wielokrotnie", co dało w sumie sto kilkadziesiąt artykułów; zob. L. Kubicki, Doświadczenie pierwszej dyskusji, „Prawo i Życie” (dalej: PiŻ) 1956, nr 11, s. 2.

${ }^{16}$ P. Codogni, Rok 1956, Warszawa 2006, s. 298.

${ }^{17}$ J. Potępa, Tendencja do zbytnich uproszczeń, „Nowe Prawo” (dalej: NP) 1956, nr 10, s. 92.

${ }^{18}$ M. Siewierski, Dyskusja nad projektem kodeksu karnego, BNRA 1956, nr 2, s. 39. 
wało, iż cała część ogólna projektu kodeksu karnego „poprzetykana” była przepisami odnoszącymi się tylko do przestępstw wojskowych, co z kolei utrudniać miało zrozumienie całości przepisów k.k. ${ }^{19} \mathrm{~W}$ innym miejscu, nie negując idei zamknięcia $w$ ramach kodeksu norm stanowiących przedmiot szeregu ustaw szczególnych, pytano, czy takie normy jak z dziedziny prawa celnego powinny znaleźć się w tym kodeksie ${ }^{20}$.

Przedmiotem krytyki stały się również ogólnikowość i brak precyzji dużej części przepisów projektu oraz niejasna terminologia. Autorzy zwracali przy tym uwagę, iż niedostateczna precyzja większości wadliwych sformułowań wynikała m.in. z opacznie rozumianej tendencji zbliżenia kodeksu do mas. Zbliżenie to miało polegać głównie na operowaniu określeniami języka potocznego, które były niewątpliwie powszechnie rozumiane, ale zbyt ogólnikowe, aby posługując się nimi można było prawidłowo, ściśle i jednoznacznie określić stan faktyczny przestępstwa. Zarzucali także, że pojęcia prawne w projekcie kodeksu karnego były tak nieokreślone, iż przy stosowaniu nowego kodeksu sędzia byłby zmuszony czerpać treść pojęć ze starego kodeksu karnego ${ }^{21}$.

Wśród dyskutantów padały głosy, iż wiele do życzenia pozostawiał niewątpliwie stalinowski język projektu, charakteryzujący się pewną sloganowością zwrotów, co było skutkiem nadużywania takich wyrażeń, jak „masy pracujące”, „socjalistyczna świadomość prawna” lub że zjawisko jakieś „zagraża interesom PRL”, wobec czego należy „wzmóc czujność mas ludowych”22. Ten zabieg doprowadzał do powstawania zbędnych deklaracji, nie dających ani organom wymiaru sprawiedliwości, ani obywatelom żadnych wskazań, mających praktyczne znaczenie. Taką deklaracją był m.in. art. 20 projektu, określający cele kary, art. 45§ 2 stanowiący, że sąd wymierzając karę, kieruje się socjalistyczną świadomością prawną i urzeczywistnia zadania polskiego ustawodawstwa karnego ${ }^{23}$.

Dużym zainteresowaniem cieszyły się zagadnienia dotyczące części ogólnej kodeksu. Choć były już przedmiotem rozmów w roku 1951 i 1955, to w kształcie przyjętym w 1956 r. nasunęła poważne wątpliwości wśród prawników zabierających tym razem głos w dyskusji. Najwięcej miejsca poświęcono problematyce systemu kar przewidzianych w projekcie kodeksu karnego. Projekt rozróżniał kary samoistne i dodatkowe. Wśród kar samoistnych znalazły się: kara pozbawienia wolności, kara pracy poprawczej, grzywna i nagana, a w stosunku do żołnierzy kara pozbawienia wolności lub służba w oddziale karnym. Karami dodatkowymi (art. 33) były: pozbawienie praw publicznych, pozbawienie praw ro-

\footnotetext{
${ }^{19}$ H. Rajzman, W sprawie przestęstw wojskowych, NP 1956, nr 7-8, s. 154.

${ }^{20}$ M. Siewierski Dyskusja nad projektem..., s. 44-45.

${ }^{21}$ J. Wilinkiewicz, Niejasna terminologia, NP 1956, nr 7-8, s. 146.

${ }^{22}$ B. Bernhaut, Językiem „referatowym...”, NP 1956, nr 7-8, s. 144.

${ }^{23}$ A. Kafarski, Przepisy zbędne i przepisy niedobre, NP 1956, nr 9, s. 92; J. Sawicki, Zbędne deklaracje,
} PiŻ 1956, nr 1, s. 2. 
dzicielskich lub opiekuńczych, zakaz zajmowania określonego stanowiska albo wykonywania zawodu lub określonej działalności, zakaz stałego pobytu na określonym obszarze państwa, przepadek mienia, przepadek rzeczy, degradacja ${ }^{24}$.

Wprowadzenie do katalogu kar samoistnych jednej kary pozbawienia wolności, która trwa najmniej miesiąc, najwyżej 15 lat, spotkało się z uznaniem ${ }^{25}$. Z zadowoleniem także przyjęto, że projekt k.k. nie przewidywał kary dożywotniego więzienia traktowanej jako kara niehumanitarna ${ }^{26}$. Krytyka rozpoczęła się w miejscu, w którym projekt wprowadził w pewnych wypadkach „sztywną" karę 25 lat pozbawienia wolności (art. $25 \$ 2$ ). Zagrażała ona w 34 wypadkach, przy czym bądź równolegle do alternatywnego zagrożenia karą śmierci, bądź niezależnie. Przedstawiciele doktryny podnosili, że jest to kara nie dająca większej gwarancji wychowania sprawcy przestępstwa w duchu zasad współżycia społecznego, nie spełniająca swego zadania prewencji ogólnej i szczególnej w stopniu większym niż przewidziana kara pozbawienia wolności 15 lat, w koń$\mathrm{cu}$, że jest to kara niehumanitarna i powinna być tak jak kara dożywotniego pozbawienia wolności wyeliminowana z przyszłego kodeksu karnego PRL ${ }^{27}$.

Z krytyką spotkała się również kara pracy poprawczej, polegająca na tym, że skazany miał odbywać ją na wolności albo w dotychczasowym miejscu pracy, albo w innym zakładzie pracy, przy czym w okresie odbywania kary (od 1 miesiąca do $1 \mathrm{roku}$ ) potrącać mu miano od 10 do $25 \%$ poborów. Autorzy projektu wskazywali, że ta nowa postać kar samoistnych przewidziana była za liczne przestępstwa, za które według dotychczasowego prawa groziła kara pozbawienia wolności do roku lub do lat $2^{28}$. Karę tę recypowano $\mathrm{z}$ ustawy o postępowaniu karno-administrcyjnym z dnia 15 grudnia $1951 \mathrm{r}$. oraz z ustawy o zabezpieczeniu socjalistycznej dyscypliny pracy z dnia 19 kwietnia $1950 \mathrm{r}$. Zarzucono autorom projektu, iż kara jest w rzeczywistości ukrytą grzywną, która stanowi przecież według art. 22 projektu odrębną samoistną postać kary ${ }^{29}$. Zdanie to podzielał również L. Lernell. Zwrócił on jednak uwagę, iż praca poprawcza mogłaby się

${ }^{24}$ Chciałam zauważyć, iż pkt 7 art. 33 mówiący o degradacji dotyczył tylko wojskowych. Wywnioskować to można było jedynie z brzmienia art. 44, który stanowił, że degradacja obejmowała utratę stopnia wojskowego.

${ }^{25}$ Zarzucony został tym samym dotychczasowy dwupodział na karę więzienia i aresztu. Przyjmując takie rozwiązanie, autorzy projektu poszli śladem wszystkich ( $\mathrm{z}$ wyjątkiem kodeksu karnego jugosłowiańskiego z 1951 r.) pozostałych ustawodawstw karnych socjalistycznych. J. Śliwowski, Czasowe ramy kary pozbawienia wolności w projekcie kk. PRL na tle przepisów socjalistycznego prawa karnego, PiP 1957, nr 1, s. 120.

${ }^{26}$ L. Hochberg, Zawoalowane dożywocie, NP 1956, nr 7-8, s. 158; J. Śliwowski, Czasowe ramy kary pozbawienia wolności w projekcie kk. PRL na tle przepisów socjalistycznego prawa karnego, PiP 1957, nr 1, s. 123-124 i 127.

${ }^{27}$ J. Śliwowski, op. cit., s. 127; L. Hochberg, op. cit., s. 158-159.

${ }^{28}$ E. S. Rappaport, Czyż nie jest to ukryta „grzywna”, NP 1956, nr 11-2, s. 117.

${ }^{29}$ Ibidem; W. Keniewski, Ławnicy sq̨du wojewódzkiego dla m.st. Warszawy dyskutuja nad projektem kodeksu karnego PRL, „Ławnik Ludowy” (dalej: ŁL) 1956, nr 7-9, s. 28-29. 
stać „poważnym instrumentem w zwalczaniu przestępczości jedynie wówczas, gdy będą w pełni wykorzystane możliwości wychowawczego oddziaływania, gdy wyrok sądowy orzekający tę karę w skutkach nie wywołujący poważnej dolegliwości stanie się środkiem moralnego potępienia czynu, gdy środowisko, opinia społeczna właśnie potępiająco oceniać będzie znaczenie wyroku, gdy wyrok stanie się przedmiotem osądu kolektywu, środowiska"30. Byli jednak i tacy, którzy pozytywnie ocenili wprowadzenie tej kary do kodeksu, podnosząc z kolei, że „dla wielu ludzi, którzy jedynie przypadkowo weszli w konflikt z prawem - więzienie, które zetknęło ich z zawodowymi przestępcami, stało się dla nich szkołą przestępczości”"

Zdecydowanie jednym głosem wypowiadano się w czasopismach prawniczych na temat kary nagany. Ówczesny wicedyrektor Departamentu w Ministerstwie Sprawiedliwości Jerzy Bafia pisał: „Dziwi czytającego, że taka kara samoistna [...] w naszych warunkach społecznych występować ma w części szczególnej kodeksu tylko w czterech przypadkach (art. 149, 151, 287 i 288). Dziwi, gdyż nie należy jej wcale wprowadzać, a najdrobniejsze przestępstwa usunąć z kodeksu, albo, jeśli zostaje wprowadzona jako kara samoistna, to winna mieć szersze

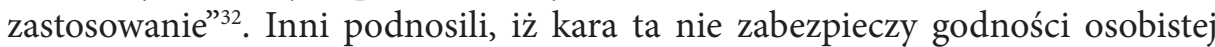
obywatela i nie będzie mogła korzystnie wpłynąć ani na wychowanie społeczeństwa, ani na poziom wymiaru sprawiedliwości i w żadnym wypadku nie będzie dla niej miejsca w postępowaniu sądowym ${ }^{33}$. Zwracano uwagę, by ten sposób wyrażania dezaprobaty wobec czyjegoś zachowania się pozostawić sądom koleżeńskim, opinii publicznej, oficerskim sądom honorowym oraz orzecznictwu karno-administracyjnemu ${ }^{34}$.

W stosunku do kary grzywny zetknęłam się tylko z jedną opinią, która nie przypisywała jej dużej roli w systemie socjalistycznego prawa karnego. Autor tej opinii postulował, by była ona wykorzystana do zwalczania przestępstw wynikających z chęci zysku czy chęci osiągnięcia korzyści majątkowej, a nie jak to miało miejsce w projekcie - głównie przestępstw najdrobniejszych ${ }^{35}$. Jednak projektodawca miał zapewne odmienne zdanie, skoro w części szczególnej grzywna jako kara samoistna wystąpiła w 72 przypadkach ${ }^{36}$.

${ }^{30}$ L. Lernell, Niektóre uwagi do projektu kodeksu karnego PRL, s. 135.

${ }^{31}$ C. Sawicz, Humanizm socjalistyczny czy nieporozumienie?, NP 1956, nr 7-8, s. 149.

${ }^{32}$ J. Bafia, Czy nie przesada...?, NP 1956, nr 10, s.105.

${ }^{33}$ C. Sawicz, op. cit., s. 152.

${ }^{34}$ B. Pakowski, Nie powinny znaleźć się w kodeksie, NP 1956, nr 10, s. 100; S. Salmonowicz, S. Waltoś, O pewnych niekonsekwencjach części ogólnej projektu kodeksu karnego, PiP 1956, nr 10, s. 677.

${ }^{35}$ J. Bafia, op. cit., s. 104.

${ }^{36}$ Zgodnie z art. 28 grzywna miała być wymierzana w wysokości od 100 zł do 100000 zł. Projekt jednak bardzo często odstępował od tej zasady, określając górną granicę kary grzywny. Przeważnie posługiwał się kwotą 5000 zł. 
Poza katalogiem kar samoistnych w projekcie kodeksu karnego ujęto karę śmierci jako karę wyjątkową, przewidzianą za najcięższe przestępstwa na czas przejściowy (art. 23 projektu k.k.). Kary tej nie przewidziano w stosunku do kobiet ciężarnych i osób, które nie ukończyły 18 roku życia. Na łamach czasopism prawniczych nie podjęto szerszej dyskusji nad zagadnieniem czy utrzymać, czy znieść karę śmierci w państwie socjalistycznym, jakim była Polska. Przedstawiciele doktryny podnosili tylko, że kara ta nie ma znamion „wyjątkowej”, występuje bowiem w 15 wypadkach, nie licząc rozdziału XXII traktującego o przestępstwach wojskowych ${ }^{37}$, a także, jeśli ma się znaleźć w kodeksie karnym, to powinna być ujęta $\mathrm{w}$ art. 22 projektu jako kara samoistna ${ }^{38}$. Ponadto przeważały głosy za oficjalnym utrzymaniem tego rodzaju kary za najcięższe przestępstwa ${ }^{39}$.

W związku z problematyką systemu kar zainteresowanie wzbudziła też kwestia stopniowania ich za poszczególne przestępstwa. Na łamach czasopism prawniczych zwrócono uwagę, że zachowując surowe sankcje karne za przestępstwa najcięższe projekt kodeksu stwarza dla sądu daleko idące możliwości indywidualizowania kary zależnie od charakteru sprawy, od osobowości sprawcy, rodzaju przestępstwa itp. Jak jednak zauważyli autorzy, ustalenie w projekcie dość często dolnej granicy kary przejawia niesłuszną nieufność do sędziego ${ }^{40}$. Kolejny zarzut odnosił się do sędziowskiego wymiaru kary. Choć sędzia miał otrzymywać wiele wskazówek, to projekt okazał się w tym miejscu niekonsekwentny. Wymieniał bowiem jakie okoliczności sąd powinien przyjąć jako okoliczności obciążające, a które jako łagodzące i w obu wypadkach używał wyrazów „w szczególności”. $\mathrm{Z}$ tego wynikało, że wyliczenie było tylko przykładowe, a więc z jednej strony stanowiło wskazówkę, a z drugiej dowolność w uzupełnieniu tej wskazówki ${ }^{41}$.

W ogniu krytyki ze strony teoretyków prawa znalazły się także inne zagadnienia części ogólnej projektu, takie jak ujęcie istoty przestępstwa, treść pojęcia społecznego niebezpieczeństwa czynu, ustawienie problemu winy. Wysuwano postulaty, by wyeliminować pojęcie społecznego niebezpieczeństwa czynu $\mathrm{z}$ ustawodawstwa i orzecznictwa. Według art. $2 \$ 1$ projektu k.k. przestępstwem miał być czyn społecznie niebezpieczny, zabroniony przez ustawę pod groźbą

${ }^{37}$ Część szczególna projektu zawierała 31 przypadków, w których przewidziano możliwość zastosowania kary śmierci, z czego aż w 2 wypadkach ta „wyjątkowa” kara była jedyną obligatoryjną karą przewidzianą za dane przestępstwo (art. 301 i 302). S. Salmonowicz, S. Waltoś, O pewnych niekonsekwencjach..., s. 677; J. Terpiłowski, Czy rzeczywiście... „wyjątkowa”?, NP 1956, nr 10, s. 96.

${ }^{38}$ B. Pakowski, Nie powinna znaleźć się w kodeksie..., s. 100.

${ }^{39}$ K. Koźniewski, Rozmyślania nad projektem kodeksu karnego, PiŻ 1956, nr 9, s. 2; R. Oździński, Dyskutujemy nad projektem Kodeksu Karnego PRL, ŁL 1956, nr 7/9, s. 58; zob. też głosy przeciwników kary śmierci: S. Erlich, Głos przeciw karze śmierci. Z dyskusji o kodeksie karnym, „Nowa Kultura” (dalej: NK) 1956, nr 28, s. 3; W. Wolter, Znieść karę śmierci, NK 1956, nr 30, s. 2.

${ }^{40}$ Z. Kubec, Miara zaufania, NP 1956, nr 10, s. 97-98; S. Pławski, Konieczność ścisłego określenia przestępstw kar, PiŻ 1956, nr 4, s. 2.

${ }^{41}$ S. Pławski, op. cit., s. 2. 
kary. Była to próba połączenia dwóch definicji: formalnej - „przestępstwem jest czyn zabroniony przez ustawę pod groźbą kary” i materialnej - „przestępstwem jest czyn społecznie niebezpieczny”. Na łamach prasy podnoszono, że „skoro przestępstwem jest tylko czyn zabroniony przez ustawę, więc tylko rzeczą ustawodawcy jest określenie tego co karalne lub niekaralne" ${ }^{\text {"2 }}$. Definicja materialna w związku z tym nie miała żadnego znaczenia. Wśród autorów byli również tacy, którzy nie odrzucając materialnej definicji przestępstwa wskazywali, że o ile w zakresie istoty przestępstwa projekt kodeksu karnego zajął raczej jasne stanowisko, o tyle w zakresie struktury czynu społecznie niebezpiecznego wprowadził zamieszanie $^{43}$. Zwracano uwagę, że definicja zawarta w art. $2 \$ 1$ projektu nie przesądzała jeszcze o tym, czy w czynie społecznie niebezpiecznym upatrywać należy kategorię „czysto” przedmiotową, czy też przedmiotowo-podmiotową. Czynić to miał $\$ 3$ tegoż artykułu („nie ma przestępstwa bez winy”) wskazując, że wina miała być stroną podmiotową społecznego niebezpieczeństwa. Wątpliwości z tym związane nasuwać miały jednak kolejne artykuły, m.in. art. $7 \S 2$ i 10. Pierwszy z tych przepisów odrywał pojęcie winy od pojęcia przestępstwa wskazując, że można $\mathrm{z}$ winy nieumyślnej popełnić czyn, który nie byłby przestępstwem, a zatem nie byłby społecznie niebezpieczny. Drugi z kolei zdawał się skłaniać ku koncepcji „czysto” przedmiotowego czynu społecznie niebezpiecznego, skoro mówił o „dopuszczeniu się" czynu. To wrażenie pogłębiać miał jeszcze art. 3 projektu. Jeżeli bowiem, jak pisał J. Feldman, „znamię niewątpliwie przedmiotowe, jakim są szkodliwe następstwa, traktuje się na jednej płaszczyźnie z wagą czynu, to tym samym daje się do zrozumienia, że i waga czynu, a więc jego całokształt pojmowany jest "czysto» przedmiotowo" ${ }^{4}$. Analiza przepisów doprowadzała dyskutantów do wniosków, że społeczne niebezpieczeństwo ma $\mathrm{w}$ projekcie dwie strony: jedną przedmiotową, drugą podmiotową, co z kolei przyczynić się miało do zaistnienia pewnych niekonsekwencji.

W kwestii pojęcia winy projekt kodeksu karnego identycznie jak kodeks karny z 1932 r. rozróżniał winę umyślną i dwa jej rodzaje - dolus directus i dolus eventualis - oraz winę nieumyślną z podziałem na lekkomyślność i niedbalstwo. W rozważaniach wskazywano w szczególności na sztuczność koncepcji dolus eventualis jako winy umyślnej oraz na trudności rozgraniczenia winy umyślnej w postaci dolus eventualis i winy nieumyślnej (lekkomyślności). Uważano za niesłuszne obejmowanie jednym pojęciem winy nieumyślnej takich dwóch bardzo różniących się stanów, przy których sprawca bądź przewiduje skutki, bądź ich nie przewiduje. A jeszcze bardziej niesłuszne było zagrożenie w części szczegól-

${ }^{42}$ E. Gol, Społeczne niebezpieczeństwo czynu, PiŻ 1956, nr 3, s. 2.

${ }^{43}$ S. Salmonowicz, S. Waltoś, op. cit., s. 675-676; J. Feldman, W sprawie „czynu społecznie niebezpiecznego", WPP 1956, nr 3, s. 252.

${ }^{44}$ S. Salmonowicz, S. Waltoś, op. cit., s. 676. 
nej takich dwóch różnych stanów jednakową sankcją karną. Propozycje zmierzały w tym kierunku, by przebudować dyspozycje i sankcje części szczegółowej projektu k.k., przewidując surowsze sankcje dla przestępstw z winy nieumyślnej oraz wyodrębniając przestępstwa popełnione $\mathrm{z}$ niedbalstwa $\mathrm{z}$ łagodniejszymi sankcjami karnymi ${ }^{45}$.

Głos w dyskusji zabrano również na temat zagadnienia błędu. Co ciekawe, pierwsze redakcje projektu kodeksu karnego nie przewidywały przepisu, który by exspressis verbis określał błąd jako okoliczność uniewinniającą, tzn. powodującą, że działanie lub zaniechanie oparte na błędzie nie byłoby przestępstwem pomimo obiektywnej niezgodności z prawem karnym. Ogłoszony w marcu 1956 roku projekt kodeksu karnego naprawił, jak pisano, „mylne stanowisko poprzednich redakcji” i wprowadził art. 10 traktujący o błędzie jako okoliczności ekskulpacyjnej ${ }^{46}$. Generalnie wprowadzenie do projektu ustawy zagadnienia błędu spotkało się z uznaniem. Z kolei konstrukcja spotkała się z zarzutami. Zwrócono przede wszystkim uwagę, że przy proponowanym ujęciu form winy oraz przepisu o błędzie nie zachodziła pełna harmonia między obydwoma ustaleniami. $\mathrm{Z}$ art. 8 wynikało mianowicie, iż przestępstwo $\mathrm{z}$ winy umyślnej zachodzi, gdy sprawca mając świadomość, że czyn jego jest społecznie niebezpieczny, chce go popełnić, natomiast $\mathrm{z}$ art. 10 wynikało, że nie zachodzi przestępstwo umyślne nie tylko wtedy, gdy sprawca nie ma świadomości (jest w błędzie) co do społecznego niebezpieczeństwa czynu, ale i wtedy, gdy jest w błędzie co do znamienia czynu. Z kolei według art. 9 przestępstwo z niedbalstwa zachodzi wtedy, gdy sprawca nie przewiduje społecznie niebezpiecznego skutku swego czynu, natomiast według art. 10, gdy nie przewiduje (znajduje się w błędzie) społecznego niebezpieczeństwa czynu lub okoliczności stanowiących znamiona przestępstwa ${ }^{47}$.

Kolejne zagadnienie, które wzbudziło szczególne zainteresowanie w dyskusji dotyczyło zamieszczonych w rozdziale XIII projektu kodeksu karnego zasad odpowiedzialności nieletnich. Po pierwsze, uwagę dyskutantów zwrócił problem granicy wieku nieletnich, rozstrzygającej o odpowiedzialności sprawcy. W projekcie odrzucono okres warunkowej odpowiedzialności nieletniego, jak to miało miejsce na gruncie kodeksu karnego z 1932 r., wprowadzając odpowiedzialność bezwarunkową, $\mathrm{z}$ wyłączeniem niedorozwoju umysłowego, choroby psychicznej lub innego zakłócenia czynności psychicznych nie pozwalających rozpoznać znaczenia czynu lub pokierować swym postępowaniem (art. 86, 87 i 14) $)^{48}$. Takie

\footnotetext{
${ }^{45}$ Z. Kozanecki, Dwie czy trzy formy winy?, NP 1956, nr 9, s. 84-86.

${ }^{46}$ Z. Papierkowski, $W$ sprawie błędu, PiŻ 1956, nr 8, s. 2.

${ }^{47} \mathrm{~W}$. Wolter, Uwagi o podmiotowej stronie czynu przestępnego w ujęciu projektu kodeksu karnego PRL, PiP 1956, nr 8/9, s. 305.

${ }^{48}$ Kodeks karny z 1932 roku uzależniał odpowiedzialność karną nieletnich między 13 a 17 rokiem życia od posiadania przez nich tzw. rozeznania, czyli takiego stopnia rozwoju umysłowego i moralnego, który by pozwolił im na rozpoznanie znaczenia czynu i kierowanie swoim postępowaniem. Projekt kodeksu karnego zrywał z tą koncepcją.
} 
rozwiązanie skłoniło do postulatu, by przesunąć granicę odpowiedzialności z lat 13 do lat $14^{49}$.

Druga kwestia, której prawnicy postanowili się bliżej przyjrzeć, wiązała się z nową koncepcją, jaką wprowadzał projekt, a mianowicie wyłączeniem postępowania karnego przed sądem w stosunku do nieletnich w wieku poniżej lat $13^{50}$. Projekt wychodził z założenia, że sprawami nieletnich do lat 13 powinny zajmować się wyłącznie organy oświatowe, mające do dyspozycji środki pedagogiczne. W tym miejscu prawnicy zwrócili uwagę na dwa problemy. Pierwszy dotyczył samego sformułowania art. 86. Podniesiono mianowicie, że ustawodawca powinien uznać czyny zabronione pod groźbą kary popełnione przez nieletnich do lat 13 za przestępstwa, jednak ze względu na ich wiek po prostu nie karaćs1. Drugi problem sprowadzał się do pytania: jakie organa oświatowe przejmą sprawy tych nieletnich w obliczu i tak ogólnie trudnej sytuacji organizacyjnej placówek oświatowych, braku wykwalifikowanych kadr wychowawców, słabej operatywności wydziałów oświaty przy radach narodowych itp. ${ }^{52}$ Przy tej kwestii warto zwrócić także uwagę na spostrzeżenia T. Sławińskiego, który w wyeliminowaniu spraw nieletnich $\mathrm{w}$ wieku 11-12 lat $\mathrm{z}$ drogi postępowania przed sądem widział ujemne konsekwencje w postaci wzmożenia poczucia bezkarności, a co za tym idzie i wzrost przestępczości. Stąd proponował przesunięcie w art. 86 wieku z 13 na 10 lat $^{53}$.

W końcu ostatni problem, jaki wyłonił się na łamach czasopism prawniczych w związku z zagadnieniem odpowiedzialności nieletnich, dotyczył możliwości wymierzenia kary pozbawienia wolności w stosunku do nieletniego, który po ukończeniu lat 15 popełnił przestępstwo zagrożone karą pozbawienia wolności na lat 25 albo karą surowszą. Kara ta mogła być orzeczona w granicach do 10 lat i nieletni miałby ją odbywać w odrębnym zakładzie karnym (art. 90 projektu) ${ }^{54}$. Przeciwko głosom akceptującym taką ewentualność, szermującym argumentem wzrastającego chuligaństwa wystąpili ci, którzy w dopuszczeniu możliwości stosowania wobec nieletniego kary pozbawienia wolności widzieli poważny krok wstecz w stosunku do tego, co już w dziedzinie zasad odpowiedzialności osiągnięto. Ich argument brzmiał: „Nieletnich należy wychowywać, a nie karać”55.

${ }^{49}$ J. Potępa, Tendencja do zbytnich uproszczeń, NP 1956, nr 10, s. 95.

${ }^{50}$ Zgodnie $\mathrm{z}$ art. 86 projektu „nie popełnia przestępstwa nieletni, który dopuścił się czynu zabronionego przez ustawę karną przed ukończeniem lat 13".

${ }^{51}$ H. Zabrodzka, Wychowywać - a nie karać!, NP 1956, nr 9, s. 90-91.

${ }^{52}$ A. Stańko, Jeszcze o nieletnich, NP 1956, nr 11-12, s. 119-120; H. Zabrodzka, op. cit., s. 91.

${ }_{53}$ T. Sławiński, Sprawy nieletnich w projekcie k.k., PiŻ 1956, nr 7, s. 2.

${ }^{54}$ Był to problem, co do którego rozwiązania autorzy projektu musieli mieć poważne wątpliwości, skoro przedstawili dwa różne i to wyłączające się wzajemnie warianty rozwiązań. Wariant pierwszy to treść przepisu art. 90. Wariant drugi - to propozycja skreślenia art. 90, czyli rezygnacja z karania nieletniego przestępcy karą pozbawienia wolności i powrót do czystej koncepcji wychowawczo-poprawczej.

${ }^{55}$ H. Zabrodzka, op. cit., s. 89-92; T. Sławiński, op. cit., s. 2. 
Z kolei zwolennicy takiego rozwiązania podnosili, iż „kodeks karny nie jest kodeksem «pieszczot społecznych» i konieczne jest zastosowanie wobec nieletniego w pewnych wypadkach środka karnego zamiast środka wychowawczego" ${ }^{\text {. }}$.

Spore zainteresowanie wzbudziła także część szczególna projektu kodeksu karnego, która przed 1956 rokiem, w przeciwieństwie do części ogólnej, nie została opublikowana. W zależności m.in. od profilu pisma interesowały autorów rozwiązania kodeksowe dotyczące konkretnych przestępstw. I tak, w „Przeglądzie Ustawodawstwa Gospodarczego" skupiono uwagę na przestępstwach gospodarczych, czyli na rozdziałach XV i XX projektu k.k. ${ }^{57}, \mathrm{w}$ „Wojskowym Przeglądzie Prawniczym" zaś na przestępstwach przeciwko obowiązkowi służby wojskowej (rozdział XXI) i na przestępstwach wojskowych (rozdział XXII) ${ }^{58}$. Przedmiotem dyskusji stały się także inne przestępstwa, szczególnie art. 131-133 traktujący o ochronie płodu ${ }^{59}$, art. 246 dotyczący chuligaństwa ${ }^{60}$, czy art. 110-120 - przestępstwa przeciwko pokojowi, ludzkości i pokojowej współpracy międzynarodowej $^{61}$.

Bardzo żywa polemika toczyła się nad zagadnieniem chuligaństwa w projekcie kodeksu karnego. Wynikało to zapewne $\mathrm{z}$ faktu, iż w dotychczasowym ustawodawstwie nie było specjalnych przepisów regulujących kwestię chuligaństwa ${ }^{62}$. Pojęcie chuligaństwa nie zostało także należycie wyjaśnione ani przez doktrynę,

${ }^{56}$ Z. Papierkowski, Wokót problemu nieletnich przestępców, NP 1956, nr 7-8, s. 157. Zwrócono przy tym uwagę na brak specjalnych zakładów przeznaczonych dla takich nieletnich i stąd potrzebę ich stworzenia. Zob. S. Salmonowicz, S. Waltoś, O pewnych niekonsekwencjach części ogólnej projektu kodeksu karnego, PiP 1956, nr 10, s. 679.

${ }^{57}$ A. Meszorer, Przestępstwa gospodarcze w projekcie kodeksu karnego PRL, „Przegląd Ustawodawstwa Gospodarczego" (dalej: PUG) 1956, nr 6, s. 205-211; C. Gofroń, Ochrona interesów gospodarczych państwa w projekcie kodeksu karnego, PUG 1956, nr 7, s. 260-262; M. Szerer, Spekulacja i niegospodarność w projekcie kodeksu karnego, PUG 1956, nr 8, s. 285-288. O przestępstwie niegospodarności pisano także w „Prawie i Życiu”: T. Cyprian, Przestępstwo niegospodarności, PiŻ 1956, nr 1, s. 2; C. Przymusiński, Przestępstwo „niegospodarności”, PiŻ 1956, nr 3, s. 2.

${ }^{58} \mathrm{~J}$. Radwański, Przestępstwa przeciwko obowiązkowi odbywania służby wojskowej według projektu k.k. PRL (Art. 311-315), WPP 1956, nr 3, s. 300-309; J. Polan-Haraschin, Zagadnienie obowiazku wierności żotnierskiej w polskim wojskowym prawie karnym, WPP 1956, nr 3, s. 275-283; T. Sójka, Kilka uwag w sprawie przestępstw przeciwko obowiązkowi stużby wojskowej i przestępstw wojskowych - w projekcie k.k., WPP 1956, nr 4, s. 407-413.

${ }^{59}$ M. Lipczyńska, Ochrona płodu w ustawie z 27.IV.1956 r. i projekcie kodeksu karnego, NP 1957, nr 1, s. 20-27.

${ }^{60}$ M. Szerer, Zagadnienie chuligaństwa w projekcie kodeksu karnego, PiP 1956, nr 7, s. 93-110.

${ }^{61}$ M. Muszkat, Projekt kodeksu karnego a problematyka pokojowego wspótistnienia, WPP 1956, nr 3, s. 323-327.

${ }^{62}$ Tylko jeden akt prawny wyraźnie wymieniał przestępstwo chuligaństwa, nie podając jednak jego definicji. Aktem tym było rozporządzenie RM z dnia 27 marca 1954 r. w sprawie przepisów meldunkowych oraz pobytu na terenie miasta st. Warszawy (Dz. U. Nr 33, poz. 79). W myśl tego rozporządzenia Prezydium Rady Narodowej w m. st. Warszawie mogło pozbawić prawa pobytu na terenie m. st. Warszawy m.in. osoby skazane za uporczywe dopuszczanie się chuligańskich wybryków ( $\$ 9$ ust. 1 pkt. 3). Z. Kubec, Zagadnienie chuligaństwa a przestępstwa przeciwko życiu i zdrowiu, „Problemy Kryminalistyki" (dalej: PK) 1956, nr 4, s. 31. 
ani przez judykaturę, choć nawet SN stale posługiwał się nim jak pojęciem bardzo dobrze znanym. Z orzeczeń SN można było jedynie wnosić, iż chuligaństwo to synonim bestialstwa, że polegało ono na brutalnym, gwałtownym sposobie działania zarówno w stosunku do osób, jak i mienia ${ }^{63}$.

Zaprojektowany art. 246 k.k. miał być odpowiedzią na powszechne wołanie o ukrócenie zjawiska, które po drugiej wojnie światowej, a ściślej w połowie lat pięćdziesiątych, uznane zostało w Polsce za problem społeczny. Początku wzrostu i zaostrzania się form chuligaństwa doszukiwano się w okresie okupacji, który spowodował ogólne rozprężenie obowiązujących norm moralnych. Chuligaństwo traktowano jako niezamierzony produkt uboczny przekształceń społecznych w okresie powojennym, zwłaszcza migracji ze wsi do miasta, rozwoju przemysłu. Zwracano uwagę na to, że chuligaństwo występowało najczęściej w dużych skupiskach ludności poddanych szybkim przemianom społecznym, że przybierało najostrzejsze formy tam, gdzie najbardziej chwiały się tradycyjne struktury społeczne. Zdaniem wielu autorów chuligaństwo stanowiło rezultat niedopatrzeń i błędów w systemie i metodach wychowania dzieci i młodzieży. Dość powszechnie wskazywano również na związek chuligaństwa z nadużywaniem alkoholu ${ }^{64}$.

W środowisku prawniczym toczyły się wówczas gorące dyskusje, gdyż nie było zgody zarówno co do konieczności uchwalenia specjalnych przepisów regulujących kwestię chuligaństwa ${ }^{65}$, jak i niezbędnej do tego prawnej formuły. Wśród teoretyków prawa wyodrębniły się dwa kierunki: zwolennicy jednego dążyli - stawiając za wzór inne państwa socjalistyczne - do wprowadzenia „chuligaństwa" jako odrębnego stanu faktycznego, zwolennicy drugiego zaś postulowali rozwiązanie problemu odpowiedzialności za chuligaństwo w części ogólnej kodeksu karnego. Drugie rozwiązanie zakładało zaostrzenie wymiaru kary za przestępstwa przewidziane w części szczególnej k.k., np. bójkę, uszkodzenie ciała, o ile zostały one popełnione w warunkach, które nadawałyby czynowi charakter chuligański.

Najwięcej trudności przyniosło jednak zdefiniowanie pojęcia chuligaństwa. $\mathrm{W}$ podejmowanych próbach $\mathrm{w}$ piśmiennictwie prawniczym i w orzecznictwie SN można było zauważyć trzy koncepcje: podmiotową, przedmiotową oraz mie-

\footnotetext{
${ }^{63}$ Zob. Chuligaństwo. Studia, pod red. J. Sawickiego, Warszawa 1956, s. 25-28.

${ }^{64}$ Z. Ostrihanska, B. Szamota, D. Wójcik, Młodociani sprawcy przestęstw o charakterze chuligańskim, Wrocław 1982, s. 11-12.

${ }^{65}$ Niektórzy autorzy stwierdzali, że odpowiednie środki do walki z chuligaństwem istniały w obowiązującym ustawodawstwie i należało tylko zacząć z nich korzystać. Zob. S. Walczak, O właściwa postawe prokuratury i sądów w walce $z$ chuligaństwem, NP 1956, nr 10. Zdaniem Z. Kubeca: „Niedostateczna przeto skuteczność naszego prawa karnego przy zwalczaniu chuligaństwa nie jest bynajmniej wynikiem braku odpowiednich norm karnych, lecz wynikiem braku należytego uświadomienia sobie przede wszystkim przez organy władzy, które powołane są do ścigania takich czynów - czym właściwie jest chuligaństwo", Z. Kubec, Zagadnienie chuligaństwa..., s. 37.
} 
szaną. Za twórcę podmiotowej koncepcji uważany był J. Sawicki, który twierdził, że specyfika przestępstw chuligańskich tkwi w ich stronie podmiotowej. Początkowo uważał on, że przestępstwa o charakterze chuligańskim popełniane są wyłącznie w celu okazania nieposzanowania dla zasad współżycia społecznego. Zwolennikami koncepcji podmiotowej byli też: M. Szerer, J. Bafia, S. Pawela, S. Pomorski, Z. Wizelberg. Z koncepcją przedmiotową natomiast szukano cech charakterystycznych chuligaństwa w obiektywie sprawdzalnych, zewnętrznych cech działania sprawcy, tj.: publiczność działania, dokonania przestępstwa z użyciem przemocy, brutalność działania, jaskrawe naruszenie spokoju i porządku publicznego czynem przestępnym, spowodowanie zagrożenia osób postronnych. Na gruncie tej teorii stał m.in. Z. Papierkowski. Z kolei w wyniku krytyki tych dwóch teorii pojawiła się koncepcja mieszana, łącząca elementy podmiotowe z przedmiotowymi. Według zwolenników tej koncepcji, zajście chuligańskie charakteryzuje nie brak „racjonalnego” celu, lecz rażąca błahość tego celu w porównaniu ze środkami, którymi posłużył się sprawca. Na stanowisku koncepcji mieszanej stali: I. Andrejew, T. Cyprian, Z. Kubec ${ }^{66}$.

Projekt w art. 246 wprowadzał następujący przepis:

$\S 1$. Kto rażąco lekceważąc zasady współżycia społecznego dopuszcza się publicznie chuligańskiego wybryku, podlega karze pozbawienia wolności do roku.

$\$ 2$. Jeżeli sprawca działa ze szczególnym zuchwalstwem albo czynem swym wywołuje szczególne zgorszenie lub oburzenie, podlega karze pozbawienia wolności od roku do lat 5.

Jak więc widać, w projekcie k.k. kwestia chuligaństwa ujęta została jako delictum sui generis. Na łamach czasopism prawniczych spotkało się to z ostrą krytyką. Po pierwsze, wskazywano, że wprowadzenie do kodeksu karnego „chuligaństwa" jako odrębnego przestępstwa było ustawodawczym nieporozumieniem ${ }^{67}$. Po drugie, nie rozstrzygając zasadności stworzenia przepisu, krytykowano jego treść, którą uznano za „płynną, bezkształtną i nieoznaczoną" ${ }^{8}$. Zdaniem H. Rota: „nie trzeba wcale osobnego przepisu mówiącego o chuligaństwie, jak to czyni ogłoszony projekt. Chodzi o to, aby nowy k.k. w części szczególnej był szeroko rozbudowany o przepisy jednoznacznie formułujące prawnokarną ochronę wypracowanych przez nasze społeczeństwo dóbr, instytucji i urządzeń społecznych, moralnych, ekonomicznych itd. [...] Sformułowanie konkretnych przepisów dotyczących tych dóbr [...] będzie tym samym oznaczało, [...] nadanie sankcji karnej konkretnym czynom określanym przez opinię społeczną jako

${ }^{66}$ Z. Ostrihanska, B. Szamota, D. Wójcik, op. cit., s. 55-57.

${ }^{67}$ M.in. Dyskusja nad chuligaństwem trwa, głos w dyskusji Z. Papierkowskiego, PiŻ 1956, nr 10, s. 2; K. Kretowicz, Przeciw ucieczce od rzeczywistości, PiP 1957, nr 2, s. 352.

${ }^{68}$ Dyskusja nad chuligaństwem trwa, głos w dyskusji B. Makowskiego, PiŻ 1956, nr 10, s. 2. 
chuligańskie, bandyckie, łobuzerskie itd." ${ }^{69}$ Poza tym zwracał uwagę, iż nie powinno się wyjaśniać jednego bliżej nieokreślonego pojęcia („chuligaństwo”), za pomocą innego, również naukowo dotąd niesprecyzowanego („zasady współżycia społecznego"), jak uczynili to autorzy projektu ${ }^{70}$. Również M. Szerer stanął na stanowisku, iż nie należy wprowadzać do kodeksu karnego przepisu tworzącego z chuligaństwa swoiste przestępstwo, gdyż czyny chuligańskie atakują niemal wszystkie możliwe przedmioty ochrony karnej (życie, zdrowie, mienie, porządek publiczny itp.). Za wystarczające uważał, by zastrzec w części ogólnej kodeksu, że gdy sądzony konkretny czyn karalny będzie miał charakter chuligański, wówczas sąd powinien okoliczność tę uwzględnić jako obciążającą ${ }^{71}$. Generalnie więc rzecz ujmując, polska doktryna prawa karnego opowiedziała się wówczas za zaostrzeniem odpowiedzialności za czyny chuligańskie bez tworzenia nowego typu przestępstwa.

Projekt kodeksu karnego z 1956 r. wywołał bardzo żywą dyskusję na łamach czasopism prawniczych i można stanowczo powiedzieć, iż miał złą opinię. Jak napisał sędzia M. Szerer w „Przeglądzie Kulturalnym”: „Odkąd zaczęła się nad nim stanowcza dyskusja, ukazało się już sporo artykułów - wszystkie bardzo krytyczne. Trudno nawet wyłowić jakiś szczególnie życzliwy głos tych, co przykładali ręki do powstania projektu. A było ich przecież wielu [...]”72.

Dyskusja nad projektem kodeksu karnego przypominała grę dwóch drużyn do jednej bramki, której nikt nie bronił. Świadczyć o tym mogą choćby artykuły L. Lernella ${ }^{73}$, którego opinia prawnicza uznała co najmniej za redaktora odpowiedzialnego za treść projektu ${ }^{74}$. Pisał on w „Życiu Warszawy”, że „[...] projekt kodeksu opracowany w latach 1951-1954 w niemałym stopniu nosi na sobie piętno dawnego okresu, kiedy schematyzm, lakiernictwo przesłaniały nam widzenie w ostrym świetle wielu zagadnień naszego życia" 75 . Słowa te powinny dziwić, gdyż wypowiadał je „twórca” o swym ostatnim „dziele”. Jednak należy pamiętać, że XX Zjazd KPZR wywarł istotnie wielki wpływ na umysły i przyniósł ożywczy prąd, który wniósł do krytyki szczerość w skali rzadko przedtem spotykanej. Nie obawiano się napisać, iż „główna wada projektu leży w tym, że został on opracowany w latach 1951-1954 [...] niedobrze wyglądała w tamtych latach nasza praworządność. Wypaczenia praktyki wymiaru sprawiedliwości znajdowały odbicie w teorii i ustawodawstwie. Wszystko to nie mogło nie odbić

\footnotetext{
${ }^{69}$ H. Rot, O chuligaństwie i zasadach współżycia społecznego, PiŻ 1956, nr 4, s. 2.

${ }^{70}$ Ibidem.

${ }^{71}$ M. Szerer, Zagadnienie chuligaństwa w projekcie kodeksu karnego, PiP 1956, nr 7, s. 96.

${ }^{72}$ M. Szerer, Projekt - pogrobowiec, „Przegląd Kulturalny” 1956, nr 28, s. 2.

${ }^{73}$ L. Lernell, Na marginesie projektu kodeksu karnego, ŻW 1956, nr 131, s. 3; idem, Niektóre uwagi do projektu kodeksu karnego PRL..., s. 129-140.

${ }^{74}$ M. Siewierski, Dyskusja nad projektem kodeksu karnego, BNRA 1956, nr 2, s. 41.

${ }^{75}$ L. Lernell, Na marginesie projektu kodeksu karnego, ŻW 1956, nr 131, s. 3.
} 
się na projekcie k.k. [...]"76. Autorowi tych słów wstyd było, że projekt kodeksu noszący na okładce datę 1956 r. stanowi dalszą jeszcze „penalizację stosunków społecznych"77.

Liczne artykuły na temat projektu kodeksu karnego i zakres problematyki poruszonej w toku podjętej dyskusji dowodzą, że była to dyskusja żywa, prowadzona ze zrozumieniem celu i znaczenia. Skoncentrowała się ona w głównej mierze wokół zagadnień ogólnych i stopniowo przechodziła do szczegółowych rozważań co do poszczególnych przepisów proponowanych w projekcie. Pod adresem projektu w zdecydowanej większości padły głosy krytyczne, stanowiące nawet bezpośredni apel o to, by stworzyć sejmową Komisję Kodyfikacyjną i przeredagować projekt, „gdyż tylko takie rozwiązanie sprawy projektu uratuje praktykę od pracy opartej na niekonsekwentnej i wątpliwej w wielu punktach ustawie" 78 . Taka Komisja powołana została zarządzeniem Prezesa Rady Ministrów z 23 sierpnia 1956 r., a podjęte przez nią prace zamknęły dyskusję nad projektem kodeksu karnego z $1956 \mathrm{r}$.

\footnotetext{
${ }^{76}$ J. Olszewski, Projekt nowy - treść stara, „Po prostu” 1956, nr 22, s. 5.

${ }^{77}$ Ibidem.

${ }^{78}$ S. Salmonowicz, S. Waltoś, op. cit., s. 679.
} 